\title{
PENINGKATAN KOMPETENSI PROFESIONAL DAN PEDAGOGIK GURU SMA DI PROVINSI JAMBI
}

\author{
The Improvement Of Professional And Pedagogic Competence Of High School \\ Teacher In Jambi Province
}

\author{
Septu Haswindy
}

\author{
Badan Penelitian dan Pengembangan Daerah Provinsi Jambi \\ Jalan R.M. Nur Atmadibrata Nomor 1A, Telanaipura, Kota Jambi, 36124 \\ E-mail:d34r.w3ndy@gmail.com
}

\begin{abstract}
The teacher is the most decisive component in the education system that must receive primary attention. The purpose of this study was to determine the Professional and Pedagogic Competence of High Schools teachers in Jambi Province and to find out the constraints experienced by teachers in improving these competencies. This research used mixed methods. The sampling technique in this study was purposive. The research sample was chosen based on the value of the Teacher Competency Test with the highest, middle and lowest value criteria. The results showed that the average understanding of professional competence of teachers in the three study samples with an average score of $84,2 \%$, and pedagogic competence with an average score of $81,4 \%$. The constraints faced by high school teachers in Jambi Province are the lack of methods and variations of teachers in teaching, inadequate learning facilities, the lack of use of technology and information in the learning process, lack of training, optimization of Subject Teachers Consultation (MGMP) and lack of appreciation for creative and accomplished teachers.
\end{abstract}

Keywords : Quality of Education, High School Teacher, Professional and Pedagogic

\begin{abstract}
Abstrak
Guru merupakan komponen paling menentukan dalam sistem pendidikan yang harus mendapat perhatian utama. Tujuan Penelitian ini adalah untuk mengetahui Kompetensi Professional dan Pedagogik guru SMA di Provinsi Jambi serta untuk mengetahui kendala-kendala yang dialami guru dalam meningkatkan kompetensi tersebut. Penelitian ini menggunakan metode campuran (mixed methods). Teknik pengambilan sampel dalam penelitian ini adalah purposive. Sampel penelitian dipilih berdasarkan nilai Uji Kompetensi Guru dengan kriteria nilai tertinggi, menengah dan terendah. Hasil penelitian menunjukan bahwa Rata-rata pemahaman kompetensi profesional guru di tiga sampel penelitian dengan skor rata-rata 84,2 \%, dan kompetensi pedagogik dengan skor rata-rata 81,4\%. Adapun kendala yang dihadapi oleh guru SMA di Provinsi Jambi adalah minimnya metode dan variasi guru dalam pengajaran, belum memadainya sarana penunjang pembelajaran, masih minimnya pemanfaatan teknologi dan informasi dalam proses pembelajaran, kurangnya pelatihan, optimalisasi Musyawarah Guru Mata Pelajaran (MGMP) dan kurangnya apresiasi terhadap guru yang kreatif dan berprestasi. Untuk itu pemerintah melalui Dinas Pendidikan Provinsi Jambi agar dapat menyediakan pelatihan bagi guru yang langsung menyentuh aspek desain pembelajaran, keterampilan menggunakan alat pembelajaran yang berbasis teknologi dan informasi. Selain itu, peran MGMP perlu ditingkatkan melalui kegiatan menyediakan pembinaan yang professional (tutor) yang dapat membimbing dan membantu guru dalam meningkatkan kinerja dan kompetensi.

Kata kunci : Mutu Pendidikan, Guru SMA, Kompetensi Profesional, Kompetensi Pedagogik

\section{PENDAHULUAN}

Guru memegang peranan utama dalam pembangunan pendidikan,

formal di sekolah. Guru juga sangat menentukan keberhasilan peserta didik, terutama dalam kaitannya dengan proses

khususnya yang diselenggarakan secara belajar mengajar. Guru merupakan
\end{abstract} 202|Khazanah Intelektual Volume 2 Nomor 2 Tahun 2018 
komponen yang berpengaruh terhadap terciptanya proses dan hasil pendidikan yang berkualitas. Oleh karena itu, upaya perbaikan apapun yang dilakukan untuk meningkatkan kualitas pendidikan tidak akan memberikan sumbangan yang siknifikan tanpa didukung oleh guru yang profesional dan berkualitas. Dengan kata lain, perbaikan kualitas pendidikan harus berpangkal dari guru dan berujung pada guru pula (Darling-Hammond, 1994, 2006).

Provinsi Jambi, yang terdiri dari 9 (sembilan) Kabupaten dan 2 (dua) Kota terdapat 210 Sekolah Menengah Atas baik negeri maupun swasta yang tersebar di 9 Kabupaten dan 2 Kota. Sedangkan jumlah guru yang mengajar pada jenjang pendidikan menengah atas ini adalah sebanyak 5137 orang. Secara kualifikasi pendidikan, berdasarkan data dari PDSPK tahun 2016, guru SMA di Provinsi Jambi telah baik dimana 97,4\% guru SMA berpendidikan minimal Sarjana.

Gambar 1 tentang hasil uji kompetensi guru menunjukkan Provinsi Jambi berada pada peringkat 22 dengan nilai rata-rata 52,25 dan nilai tersebut berada dibawah rata-rata nilai nasional, yaitu 56,69. Sedangkan untuk hasil uji kompetensi guru perjenjang pada tingkat SMA.

Gambar 2 tentang hasil ujian nasional hasil ujian nasional siswa SMA di Provinsi Jambi menunjukkan penurunan pada tahun 2016 jika dibandingkan dengan hasil ujian nasional pada tahun 2015.

\section{UI KOMPETENSI GURU}

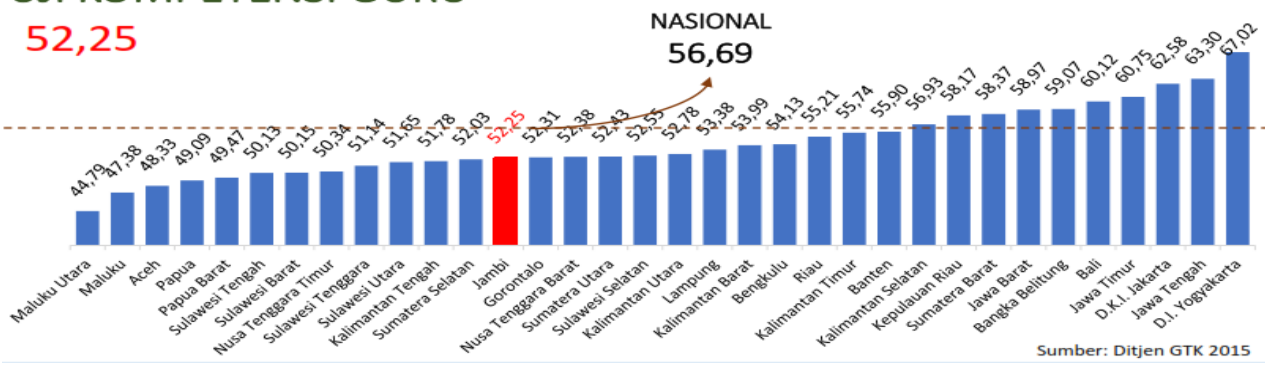

Gambar 1. Hasil Uji Kompetensi Guru
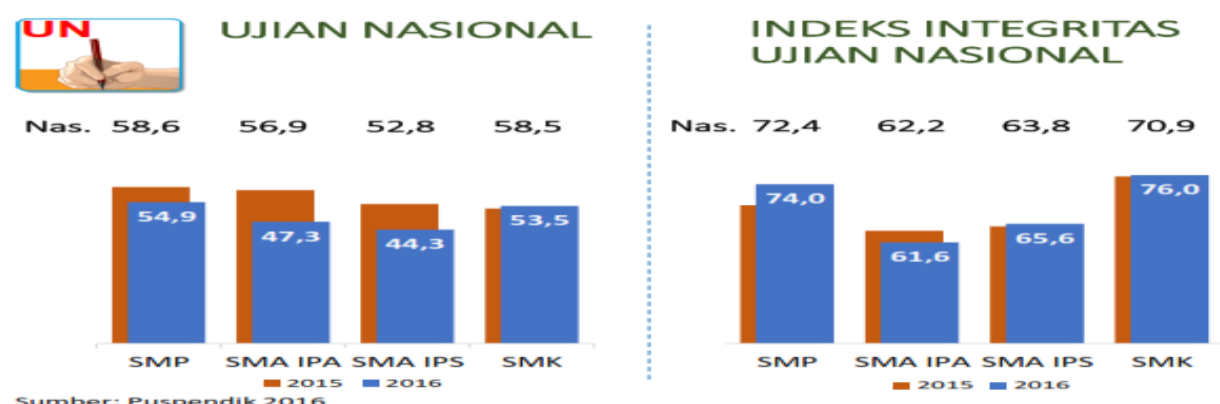

Gambar 2. Hasil Ujian Nasional Siswa SMA di Provinsi Jambi 
Penelitian ini bertujuan untuk a) pembelajaran peserta didik yang mengetahui Gambaran kompetensi meliputi pemahaman terhadap peserta profesional dan pedagogik guru SMA di didik, perancangan dan pelaksanaan Provinsi Jambi, b) mengetahui kendala pembelajaran, evaluasi hasil belajar, yang dihadapi guru SMA di Provinsi dan pengembangan peserta didik untuk jambi dalam usahanya meningkatkan kompetensi profesional dan pedagogik.

\section{Tinjauan Pustaka}

Peraturan Menteri Pendidikan Nasional Republik Indonesia Nomor 16 Tahun 2007 tentang Standar Kualifikasi Akademik dan Kompetensi Guru. Dijelaskan bahwa Standar Kompetensi Guru dikembangkan secara utuh dari 4 kompetensi utama, yaitu: (1) kompetensi pedagogik; (2) kepribadian; (3) sosial; dan (4) profesional. Keempat kompetensi tersebut terintegrasi dalam kinerja guru.

Penjabaran mengenai Kualifikasi dan Kompetensi Guru diatur dalam Peraturan Menteri Pendidikan Nasional (Permendiknas) Nomor 16 Tahun 2007 tentang Standar Kualifikasi dan Kompetensi Guru. Kompetensi Guru menurut Permendiknas Nomor 16 Tahun 2007 dikembangkan secara utuh dari empat kompetensi utama, meliputi kompetensi pedagogik, kompetensi profesional, kompetensi kepribadian, dan kompetensi sosial. Standar Nasional Pendidikan menjabarkan bahwa kompetensi pedagogik merupakan kemampuan mengelola mengaktualisasikan berbagai potensi yang dimilikinya.

Kompetensi pedagogik adalah kemampuan guru dalam mengelola pembelajaran. Kompetensi pedagogik terdiri dari delapan indikator. Indikator pertama adalah pemahaman wawasan atau landasan kependidikan. Guru memiliki latar belakang pendidikan keilmuan sehingga memiliki keahlian secara akademik dan intelektual. Merujuk pada sistem pada sistem pengelolaan pembelajaran yang berbasis subjek (mata pelajaran), guru seharusnya memiliki pengetahuan dan pengalaman dalam penyelenggaraan pembelajaran di kelas. Secara otentik kedua hal tersebut dapat dibuktikan dengan ijazah akademik dan ijazah keahlian (akta mengajar) dari lembaga pendidikan yang diakreditasi pemerintah. Kusnandar (2007), mengemukakan bahwa dalam memahami wawasan atau landasan kependidikan guru harus mempelajari konsep dan masalah pendidikan dengan sudut tinjauan sosiologis, filosofis, historis dan psikologis serta mengenali fungsi sekolah sebagai lembaga sosial yang secara potensial dapat memajukan 
masyarakat dalam arti luas serta pengaruh timbal balik antara sekolah dengan masyarakat.

Indikator kedua adalah pemahaman terhadap peserta didik. Guru diharapkan memiliki pemahaman akan psikologi perkembangan anak, sehingga mengetahui dengan benar pendekatan yang tepat untuk diterapkan pada anak didiknya. Selain itu, guru memiliki pengetahuan dan pemahaman terhadap latar belakang pribadi anak, sehingga dapat mengidentifikasi masalah-masalah yang dihadapi anak serta menentukan solusi dan pendekatan yang tepat.

Indikator berikutnya adalah pengembangan kurikulum atau silabus. Masnur Muslich (2007: 23), memberikan definisi silabus sebagai garis besar, ringkasan, ikhtisar atau pokok-pokok isi atau materi pelajaran. Sedangkan Mulyasa (2007: 190), menyatakan pengertian silabus sebagai suatu rencana pembelajaran pada suatu kelompok mata pelajaran dengan nama tertentu yang mencakup standar kompetensi, kompetensi dasar, materi pembelajaran, indikator, penilaian, alokasi waktu dan sumber belajar yang dikembangkan oleh setiap satuan pendidikan. Silabus dalam KTSP merupakan penjabaran standar kompetensi dan kompetensi dasar ke dalam materi pembelajaran, kegiatan pembelajaran dan indikator pemaparan kompetensi untuk penilaian belajar.

Indikator keempat adalah perancangan pembelajaran. Guru harus dapat merencanakan sistem pembelajaran yang memanfaatkan sumber daya yang ada. Semua aktivitas pembelajaran dari awal sampai akhir telah dapat direncanakan secara strategis, termasuk antisipasi masalah yang kemungkinan dapat timbul dari skenario yang direncanakan. Perencanaan jangka pendek diperlukan untuk memperkirakan atau memproyeksikan apa yang akan dilakukan dalam pembelajaran. Rencana Pelaksanaan Pembelajaran (RPP) merupakan upaya untuk memperkirakan tindakan yang akan dilakukan dalam kegiatan pembelajaran. RPP sedikitnya mencakup tiga kegiatan, yaitu identifikasi kebutuhan, perumusan kompetensi dasar, dan penyusunan program pembelajaran (Mulyasa, 2007). Indikator kelima adalah Pelaksanaan pembelajaran yang mendidik dan dialogis. Secara teknis pelaksanaan kegiatan pembelajaran menampakkan pada beberapa hal, yaitu pengelolaan tempat belajar/ruang kelas, pengelolaan bahan pelajaran, pengelolaan kegiatan dan waktu, pengelolaan siswa, pengelolaan sumber belajar dan pengelolaan perilaku mengajar (Muslich, 2007). 
Indikator keenam adalah pemanfaatan teknologi pembelajaran. Guru seharusnya menggunakan teknologi sebagai media pembelajaran. Penggunaan teknologi dalam pendidikan dan pembelajaran (e-learning) dimaksudkan untuk memudahkan atau mengefektifkan kegiatan pembelajaran (Mulyasa, 2007). Oleh karena itu, guru dan calon guru dibekali dengan berbagai kompetensi yang berkaitan dengan penggunaan teknologi informasi dan komunikasi sebagai teknologi pembelajaran.

Indikator ketujuh adalah evaluasi hasil belajar. Evaluasi hasil belajar merupakan suatu upaya untuk mengadakan penilaian terhadap apa yang sudah dikerjakan, mulai dari perencanaan sampai dengan pelaksanaan selesai dikerjakan. Evaluasi dilakukan untuk mengetahui bagianbagian mana dari sederetan kegiatan tersebut yang belum mencapai sasaran dan mengumpulkan informasi tentang penyebabnya dan evaluasi tersebut diharapan dapat memperbaiki langkah yang akan datang (Arikunto, 2002).

Indikator terakhir adalah pengembangan peserta didik untuk mengaktualisasikan berbagai potensi yang dimilikinya. Guru seharusnya memiliki kemampuan untuk membimbing anak, menciptakan wadah bagi anak untuk mengenali potensinya dan melatih untuk mengaktualisasikan potensi yang dimiliki. Oleh karena itu, terdapat tiga kegiatan yang harus dilaksanakan guru dalam pengembangan peserta didik sesuai dengan minat dan bakat siswa, yaitu : (1) pengayaan dan remedial; (2) bimbingan; dan (3) konseling pendidikan (Mulyasa, 2007).

Kompetensi profesionalisme guru berhubungan dengan kompetensi yang menuntut guru untuk ahli di bidang pendidikan sebagai suatu pondasi yang dalam melaksanakan profesinya sebagai seorang guru profesional. Karena dalam menjalankan profesi keguruan, terdapat kemampuan dasar dalam penegetahuan tentang belajar dan tingkah laku manusia, bidang studi yang dibinanya, sikap yang tepat tentang lingkungan belajar mengajar dan mempunyai keterampilan dalam teknik mengajar (Mulyasa, 2011).

\section{METODE PENELITIAN}

Metode yang digunakan dalam penelitian ini adalah metode mixed methods (Creswell, 2011). Pada tahap awal metode penelitian ini menggunakan metode kualitatif dan tahap berikutnya mengunakan metode kuantitatif. Penekanan metode lebih pada metode pertama, yakni kualitatif dan selanjutnya dilengkapi dengan metode kuantitatif berupa survei. 
Pencampuran data kedua metode bersifat connecting (menyambung) antara hasil pertama dan tahap berikutnya.

Populasi penelitian ini adalah Sekolah Menengah Atas di Provinsi Jambi yang terdiri atas 2 Kota (Kota Jambi dan Kota Sungai Penuh) dan 9 kabupaten (Kabupaten Muaro Jambi, Kabupaten Batanghari, Kabupaten Tanjung Jabung Timur, Kabupaten Tanjung Jabung Barat, Kabupaten Tebo, Kabupaten Merangin, Kabupaten Sarolangun, Kabupaten Merangin dan
Kabupaten Kerinci). Sampel dipilih berdasarkan nilai Uji Kompetensi Guru dengan kriteria nilai tertinggi, menengah dan terendah. Teknik pengambilan sampel adalah purposive, masingmasing dipilih satu Kabupaten/Kota. Adapun Kabupaten atau Kota yang menjadi sampel penelitian dapat dilihat pada Tabel 1 tentang sampel penelitian.

Dalam penelitian ini, kepala sekolah, dan semua guru pada Sekolah Menengah Atas di Provinsi Jambi adalah sampel dari penelitian ini

Tabel 1. Sampel Penelitian

\begin{tabular}{clcc}
\hline No & \multicolumn{1}{c}{ Sampel } & Persentase Nilai UKG & Keterangan \\
\hline $\mathbf{1}$ & Kota Jambi & 56,36 & Tertinggi \\
$\mathbf{2}$ & Kab.Tanjung Jabung Barat & 52,15 & Sedang \\
$\mathbf{3}$ & Kab. Kerinci & 48,27 & Terendah \\
\hline
\end{tabular}

Ada dua cara pengumpulan data dalam penelitian ini, yaitu pertama, melalui Diskusi Kelompok Terarah atau biasa dikenal dengan FGD (Focus Group Discussion) dan kedua adalah angket. Pelaksanaan FGD ditujukan untuk Kepala Sekolah SMA pada setiap daerah sampel penelitian.

Instrumen selain FGD yang digunakan dalam penelitian ini adalah Angket. Angket disini adalah daftar pertanyaan yang dibuat peneliti tentang kompetensi profesional dan pedagogik guru Sekolah Menengah Atas di Provinsi Jambi. Bentuk angket yang dibuat peneliti adalah angket tertutup berisi daftar pertanyaan yang mengharapkan responden untuk memilih salah satu alternatif jawaban dari setiap pertanyaan yang telah disediakan. Angket yang digunakan bersifat tertutup dengan lima alternatif jawaban, yaitu Selalu, Sering, Kadang-Kadang, dan Tidak Pernah. Dalam pengumpulan data perlu berpedoman pada indikator-indikator yang ditetapkan.

Data yang berhasil dikumpulkan melalui FGD dan angket kemudian dianalisis dengan teknik yang berbeda untuk menjawab masing-masing rumusan masalah. Untuk rumusan 
masalah pertama, data tentang diagram kompetensi profesional dan pedagogik guru SMA di Provinsi Jambi yang didapatkan dari angket yang diisi oleh guru akan dianalisis dengan SPSS. Untuk rumusan masalah yang kedua tentang kendala yang dihadapi guru SMA terkait kompetensi profesional dan pedagogik dari hasil FGD dan angket akan dianalis dengan menggunakan analisis tema.

\section{HASIL DAN PEMBAHASAN}

\section{Profil Responden}

Sebagaimana yang terlihat pada Tabel 2 tentang Jumlah Responden yang Tersebar Pada Tiga Kabupaten/Kota di Provinsi Jambi, terdapat dua Kabupaten dan satu Kota yang tergabung dalam penilitian ini, yaitu Kota Jambi, Kabupaten
Tanjung Jabung Barat, dan Kabupaten Kerinci. Persentase guru yang ada di Kota Jambi mencapai $50 \%$ atau sebanyak 588 guru yang merupakan jumlah paling banyak dibandingkan dengan kedua Kabupaten lainnya.

Sedangkan jumlah guru yang ada di Kabupaten Tanjung Jabung Barat yang terlibat untuk menjadi responden penelitian ini merupakan yang terendah, yaitu hanya $22 \%$ atau sebanyak 260 guru. Namun, jumlah persentase tersebut tidak jauh dengan Kabupaten Kerinci, yaitu hanya $28 \%$ atau sebanyak 329 guru. Sehingga jumlah keseluruhan responden yang terlibat dalam penelitian ini sebanyak 1.177 guru yang tersebar pada ketiga Kabupaten/Kota di Provinsi Jambi.

Tabel 2. Jumlah Responden yang Tersebar Pada Daerah Sampel Penelitian

\begin{tabular}{|l|c|c|}
\hline Kabupaten/Kota & Frequency & $\begin{array}{c}\text { Persentas } \\
\text { e }\end{array}$ \\
\hline Kota Jambi & 588 & $50 \%$ \\
\hline Tanjung Jabung Barat & 260 & $22 \%$ \\
\hline Kerinci & 329 & $28 \%$ \\
\hline Total & 1177 & $100 \%$ \\
\hline
\end{tabular}

Tabel 3 tentang karakteristik status Pegawai Tidak Tetap (baik responden berdasarkan status tenaga honorer pada sekolah negeri kepegawaian menunjukkan bahwa maupun tenaga kontrak pada sekolah mayoritas responden penelitian ini swasta) mencapai $14,9 \%$, dengan total adalah Guru dengan jabatan Pegawai responden sebanyak 175 Guru. Negeri Sipil (PNS). Persentasenya Sedangkan untuk guru dengan status mencapai 24,6\% atau sebanyak 290 pegawai Yayasan (pada sekolah Guru. Sedangkan untuk guru dengan swasta) mencapai 9,6\%, dengan total 
responden sebanyak 113 Guru. Akan tidak tercantum jabatannya, atau tetapi terdapat 50,9 \% responden yang sebanyak 599 Guru.

Tabel 3. Karakteristik Responden Berdasarkan Status Kepegawaian

\begin{tabular}{l|c|c|}
\hline Jabatan Guru & Frekuensi & Persentase \\
\hline PNS & 290 & 24,6 \\
\hline PTT & 175 & 14,9 \\
\hline YAYASAN & 113 & 9.6 \\
\hline Tidak Tercantum & 599 & 50,9 \\
\hline Total & 1177 & 100,0 \\
\hline
\end{tabular}

KOMPETENSI PROFESIONAL GURU SMA DI KOTA JAMBI, KABUPATEN TANJUNG JABUNG BARAT DAN KABUPATEN KERINCI

Indikator Menjelaskan Materi

\section{Pembelajaran Dengan Jelas}

Diagram di atas menunjukkan hasil terperinci tentang indikator menjelaskan materi pembelajaran dengan jelas, sebanyak $62 \%$ guru di Kota Jambi selalu menjelaskan materi pembelajaran dengan jelas, 34\% sering menjelaskan materi pembelajaran dengan jelas, dan 4\% kadang-kadang menjelaskan materi pembelajaran dengan jelas.

Selanjutnya, diagram di bawah menunjukkan hasil terperinci tentang indikator menjelaskan materi pembelajaran dengan jelas, sebanyak 55\% guru Kabupaten Tanjung Jabung Barat selalu menjelaskan materi pembelajaran dengan jelas, $40 \%$ sering menjelaskan materi pembelajaran dengan jelas, dan 5\% kadang-kadang menjelaskan materi pembelajaran dengan jelas.

Grafik 1 di bawah menunjukkan hasil terperinci tentang indikator menjelaskan materi pembelajaran dengan jelas, sebanyak $62 \%$ guru di Kabupaten Kerinci selalu menjelaskan materi pembelajaran dengan jelas, $36 \%$ sering menjelaskan materi pembelajaran dengan jelas dan 3\% kadang-kadang menjelaskan materi pembelajaran dengan jelas.

\section{Grafik 1. Menjelaskan Materi Pembelajaran dengan} Jelas

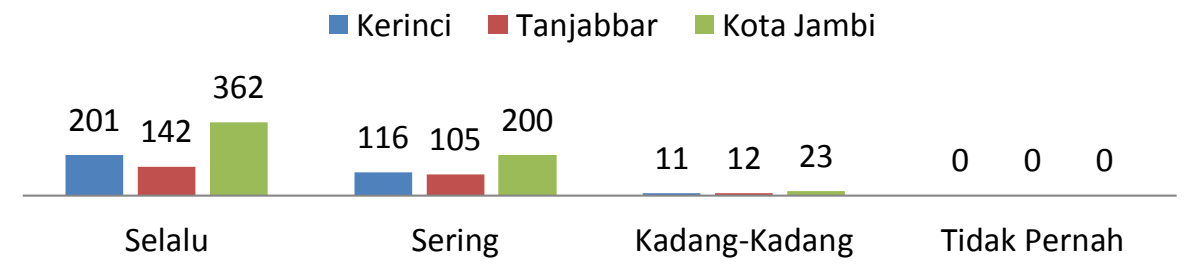

Peningkatan Kompetensi Profesional Dan Pedagogik Guru SMA 
Menyimpulkan Materi Pembelajaran

Indikator selanjutnya adalah menyimpulkan materi pembelajaran sebagaimana terlihat pada Grafik 2 menunjukkan sebanyak $47 \%$ guru di Kota Jambi selalu menyimpulkan materi pembelajaran, $41 \% \quad$ sering menyimpulkan materi pembelajaran, dan $12 \%$ kadang-kadang menyimpulkan materi pembelajaran. Kabupaten Tanjung Jabung Barat, terdapat sebanyak $47 \%$ guru SMA selalu menyimpulkan materi pembelajaran,
$46 \%$ sering, menyimpulkan materi pembelajaran, dan 7\% kadang-kadang menyimpulkan materi pembelajaran.

Selanjutnya, Kabupaten Kerinci terdapat sebanyak 55\% guru SMA selalu menyimpulkan materi pembelajaran, $\quad 39 \% \quad$ sering menyimpulkan materi pembelajaran, 6\% kadang-kadang menyimpulkan materi pembelajaran dan hanya 1\% yang tidak pernah meyimpulkan materi pembelajaran.

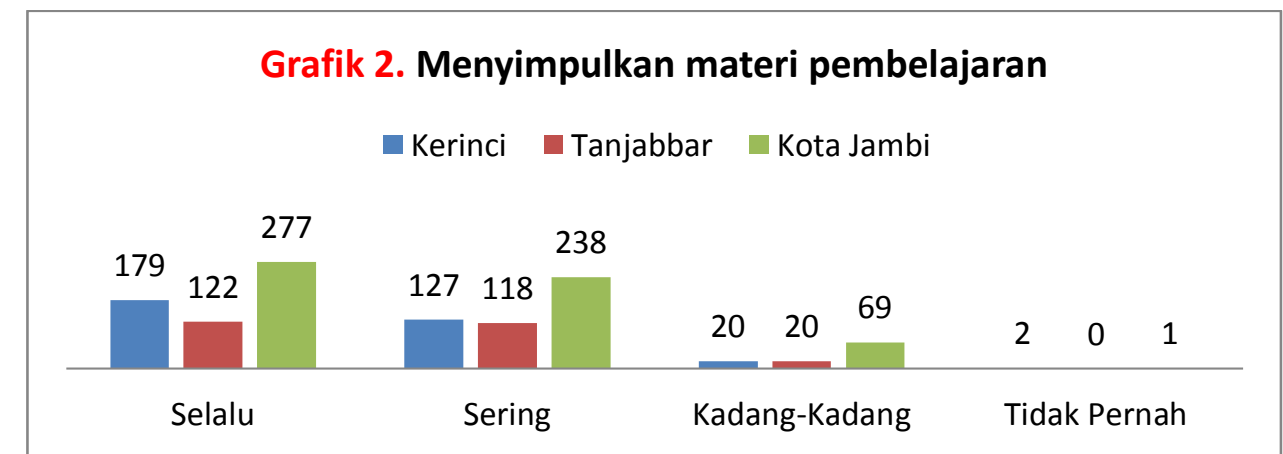

Kompetensi Pedagogik Guru SMA di

\section{Provinsi Jambi}

Kompetensi pedagogik guru dalam memahami peserta didik di Kota Jambi mengambarkan hasil pemahaman Guru terhadap peserta didik di Kota Jambi. Dalam meningkatkan kecerdasan siswa, para guru sering menerapkan sistem pembelajaran berbasis Teknologi Informasi (TI) dan menerapkan pembelajaran dengan latihan untuk meningkatkan kreativitas siswa. Namun para guru kadang-kadang membuat mading juga. Dalam meningkatkan prestasi belajar siswa, para guru selalu memberikan motivasi. Para guru juga selalu bersikap objektif dalam melakukan penilaian terhadap siswa. Dalam penerapan metode pembelajaran guru sering menggunakan metode bervariasi, kadang-kadang melakukan pembelajaran di luar kelas menerapkan metode role play disetiap pembelajaran. 


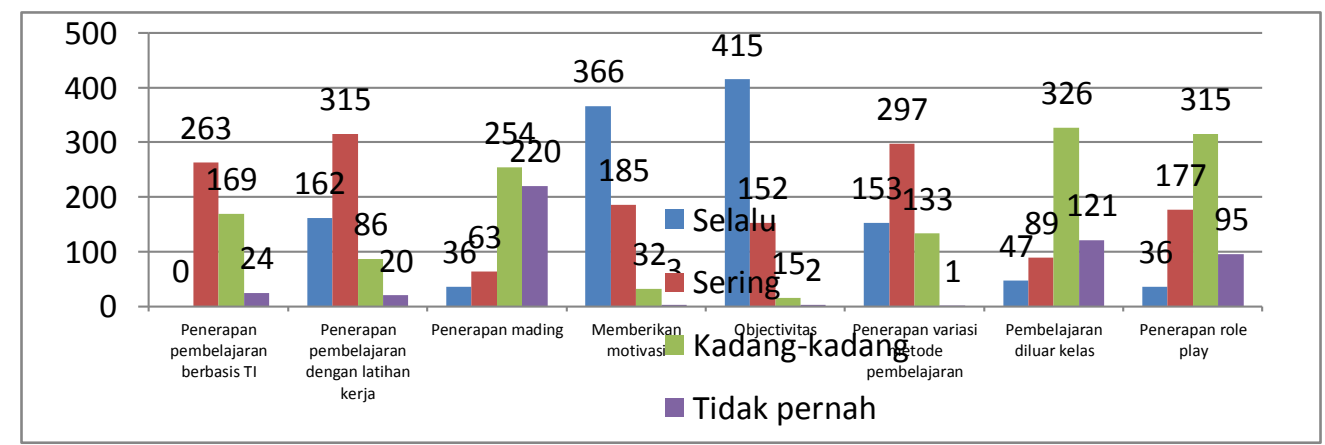

Grafik 3. Kompetensi Pedagogik Guru Dalam Memahami Peserta Didik di Kota Jambi

Kompetensi pedagogik guru dalam para guru membuat mading juga. Dalam memahami peserta didik di Kabupaten meningkatkan prestasi belajar siswa, Tanjung Jabung Barat menunjukkan para guru selalu memberikan motivasi. hasil pemahaman Guru terhadap Para guru juga selalu bersikap objektif peserta didik di Kabupaten Tanjung dalam melakukan penilaian terhadap Jabung Barat. dalam meningkatkan siswa. Dalam penerapan metode kecerdasan siswa, para guru kadang- pembelajaran guru sering menggunakan kadang menerapkan sistem metode bervariasi, kadang-kadang pembelajaran berbasis TI. Para guru melakukan pembelajaran di luar kelas, juga sering menerapkan pembelajaran dan kadang-kadang menerapkan role dengan Latihan untuk meningkatkan play disetiap pembelajaran. kreativitas siswa dan kadang-kadang

Grafik 4. Kompetensi Pedagogik Guru Dalam Memahami Peserta Didik di Kabupaten Tanjung Jabung Barat

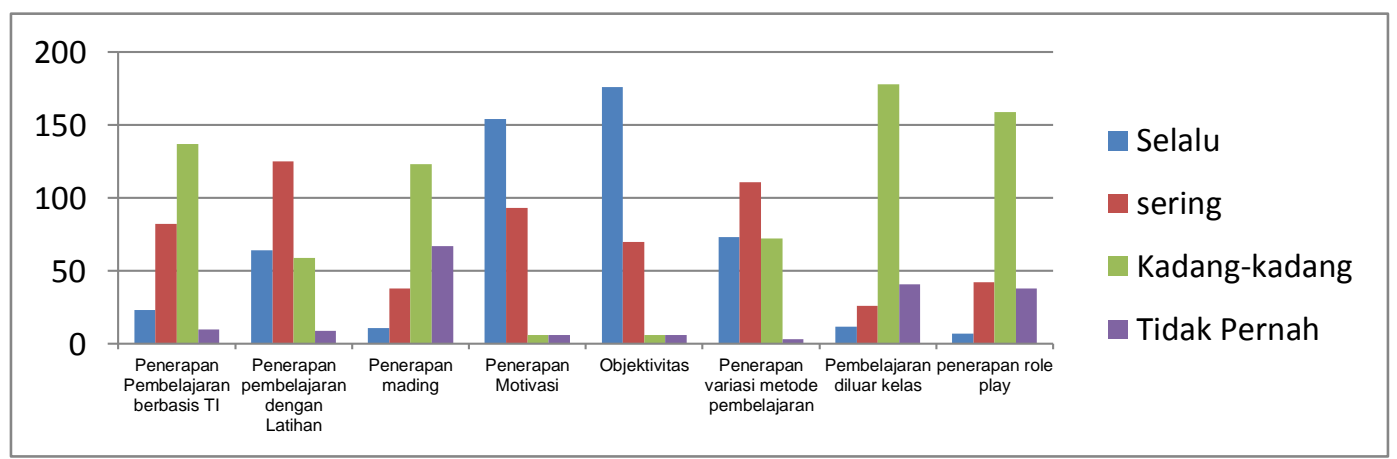

Kompetensi Pedagogik Guru SMA di Guru terhadap peserta didik di

\section{Kabupaten Kerinci}

Kompetensi pedagogik guru dalam memahamipeserta didik di Kabupaten Kerinci menunjukkan hasil pemahaman Kabupaten Kerinci.

Dalam meningkatkan kecerdasan siswa, para guru sering menerapkan sistem pembelajaran berbasis Teknologi 
Informasi (TI). Para guru juga sering siswa dan kadang-kadang para guru menerapkan pembelajaran dengan membuat mading juga.

Latihan untuk meningkatkan kreativitas

Grafik 5. Kompetensi Pedagogik Guru Dalam Memahami Peserta Didik di Kabupaten Kerinci

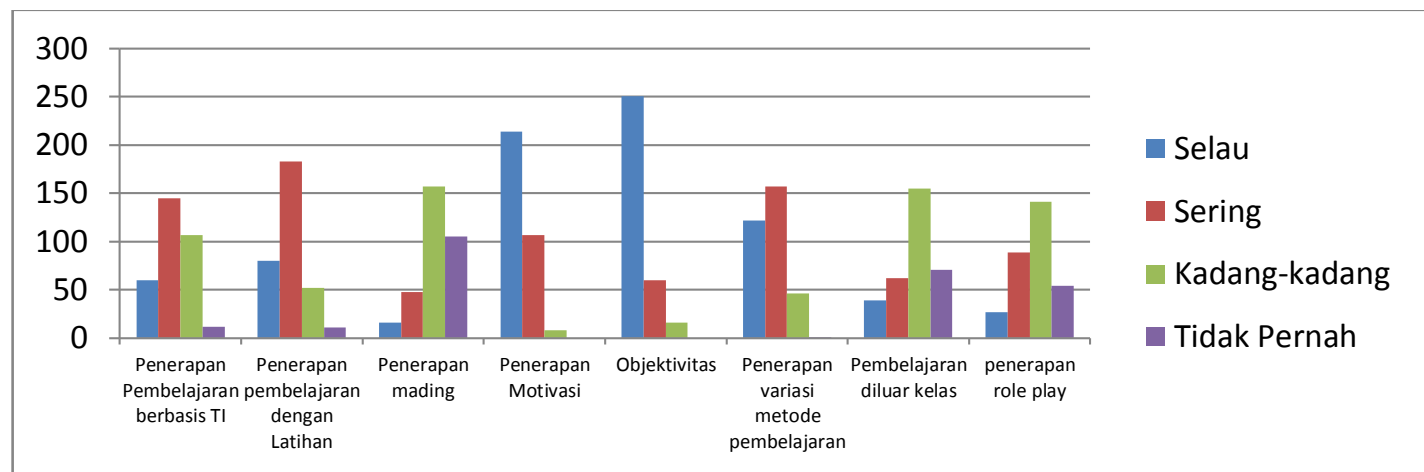

Dalam meningkatkan prestasi kompetensi guru SMA di Provinsi Jambi. belajar siswa, para guru selalu Adapun hasil dari pengumpulan angket memberikan motivasi. Para guru juga menunjukkan gambaran cukup bagus selalu bersikap objektif dalam namun masih terdapat beberapa melakukan penilaian terhadap siswa. indikator pada kompetensi pedagogik Dalam penerapan metode dan kompetensi profesional guru SMA pembelajaran, guru sering yang perlu mendapatkan perhatian. menggunakan metode bervariasi, kadang-kadang melakukan pembelajaran di luar kelas dan kadangkadang menerapkan role play disetiap pembelajaran.

Kendala Yang Berhubungan Dengan Kompetensi Profesional dan Pedagogik Guru SMA di Provinsi Jambi Berdasarkan Hasil FGD

Minimnya Metode dan Variasi Guru dalam Pengajaran

Berdasarkan hasil penilaian sendiri (self-evaluation) tentang kompetensi pedagogik dan kompetensi profesional pada tiga daerah sampel menyajikan materi pembelajaran, penggunaan media sebagai sumber belajar, sumber belajar untuk pengalaman belajar, sumber belajar untuk memperkaya wawasan, menciptakan kegiatan berbeda dalam menyajikan materi pembelajaran.

Untuk indikator menciptakan kegiatan dalam menyajikan pembelajaran dan menciptakan kegiatan berbeda dalam menyajikan materi pembelajaran juga muncul dalam diskusi kelompok terarah dengan kepala penelitian didapatkan gambaran kondisi sekolah SMA di tiga daerah sampel 212|Khazanah Intelektual Volume 2 Nomor 2 Tahun 2018 
penelitian. Lebih lanjut dalam diskusi kelompok terarah disebutkan bahwa cukup banyak guru di sekolah yang mereka pimpin masih menerapkan metode pengajaran yang masih bersifat monoton/tradisional dengan menggunakan metode ceramah. Hal ini sesuai dengan gambaran angket yang dikumpulkan, dimana pada SMA di Kota Jambi terdapat $11 \%$ guru menjawab tidak pernah menciptakan kegiatan berbeda dalam menyajikan materi pembelajaran, sedangkan untuk Kabupaten Tanjung Jabung Barat, terdapat $18 \%$ dan untuk Kabupaten Kerinci terdapat $42 \%$.

Padahal, banyak literatur yang menyebutkan bahwa variasi dalam pembelajaran memiliki keterkaitan dengan prestasi belajar (Djamarah dan Zain, 2002). Penggunaan media dalam proses belajar mengajar dapat menstimulasi dan meningkatkan motivasi belajar siswa sehingga perhatian siswa terhadap materi pembelajaran dapat lebih meningkat (Sanjaya, 2008).

\section{Belum Memadainya}

Sarana

\section{Penunjang Pembelajaran}

Hasil angket yang disebarkan kepada guru sebagaimana terlihat pada Diagram 4.31, 4.32, dan 4.33 tentang saran peningkatan kompetensi pedagogik dan profesional guru SMA di Kabupaten Kerinci, Tanjung Jabung
Barat dan Kota Jambi menunjukkan kendala yang dihadapi guru dalam menerapkan metode dan variasi dalam pengajaran adalah minimnya sarana penunjang pembelajaran. Hasil olah data angket Kabupaten Kerinci menunjukkan bahwa $47 \%$ dari total responden menyatakan minimnya sarana penunjang pembelajaran. Sedangkan untuk Kabupaten Tanjung Jabung Barat, hasil olah data memperlihatkan $30 \%$ dari responden mengeluhkan minimnya sarana penunjang pembelajaran. Sedangkan untuk hasil olah data angket di Kota Jambi menunjukkan $17 \%$ responden menyatakan bahwa sarana penunjang pembelajaran masih dirasa kurang.

Kondisi ini senada dengan hasil diskusi kelompok terarah, dimana sebagian besar kepala sekolah menyatakan bahwa minimnya infokus menjadi faktor utama yang menyebabkan guru tidak menerapkan variasi dan metode dalam pengajaran. Selain itu, kepala sekolah juga menyebutkan kurangnya media belajar di sekolah mereka disebabkan oleh belum terinventarisirnya media belajar di hampir semua sekolah yang menjadi responden penelitian dan dalam membuat media pembelajaran biasanya guru menggunakan uang pribadi.

Pentingnya sarana penunjang pengajaran seperti penggunaan media 
yang bervariasi mampu membangkitkan minat belajar siswa. Hal tersebut sesuai dengan salah satu fungsi dan manfaat penggunaan media pembelajaran yang disampaikan oleh Sanjaya (2008:209) bahwa penggunaan media dapat menambah motivasi belajar siswa sehingga perhatian siswa terhadap materi pembelajaran dapat lebih meningkat.

\section{Minimnya Pemanfaatan TI Dalam}

\section{Proses Pembelajaran}

Saat ini, teknologi menjadi sesuatu hal yang sangat penting dalam kehidupan manusia. Berbagai macam teknologi diciptakan untuk mempermudah kehidupan manusia. Tidak terkecuali dalam dunia pendidikan, teknologi informasi dan komunikasi (TIK) juga dapat menunjang guru dalam kegiatan belajar mengajar.

Laptop, tablet, komputer dan telepon genggam dengan cepat memainkan peran penting dalam pendidikan (Prensky, 2004). Sebuah literatur review tentang penelitian penggunaan TIK dari negara UK (United Kingdom) yang menyatakan bahwa agar perangkat teknologi tertentu dapat digunakan memerlukan kondisi-kondisi tertentu seperti tablet akan optimal digunakan jika menggunakan jaringan internet nirkabel (wifi) dan proyektor/infocus (Savil-Smith dan Kent, 2003).
Penggunaan TIK dalam proses belajar mengajar pada daerah sampel penelitian masih sangatlah kurang bahkan untuk SMA yang berada di Kota Jambi. Sebagaimana yang tergambar dari diagram 34 tentang penerapan pembelajaran berbasis TI di Kota Jambi, 4\% dari responden menyatakan tidak pernah menggunakan atau menerapkan $\mathrm{TI}$ dan 29\% menyatakan kadangkadang.

Hasil diskusi kelompok terarah dengan kepala sekolah SMA di Kota Jambi juga mengungkapkan kondisi yang sama. Cukup banyak guru SMA di Kota Jambi yang udah menerapkan penggunaan teknologi dalam proses belajar mengajar dan sisanya terkendala dengan kemampuan penguasaan teknologi yang disebabkan oleh beberapa faktor seperti umur, kemauan yang kurang dalam menggunakan teknologi dan kurangnya jumlah perangkat yang menyebabkan guru harus bergantian dalam menggunakan perangkat tersebut.

Untuk Kabupaten Tanjung Jabung Barat, hasil olah data angket menunjukkan $4 \%$ dari responden menyatakan tidak pernah menggunakan TI dalam proses pembelajaran dan $54 \%$ menyatakan kadang-kadang menggunakannya. Kondisi ini diperkuat oleh hasil diskusi kelompok terarah dengan kepala sekolah di Kabupaten 
Tanjung Barat yang menyatakan bahwa sebagian besar guru mereka masih belum menguasai teknologi dan minimnya perangkat teknologi seperti laptop, komputer dan proyektor/infocus menjadi penyebab utamanya. Selain itu, cukup banyak SMA yang secara geografis berada di daerah yang belum dijangkau oleh akses internet.

Penerapan pembelajaran berbasis TI di Kabupaten Kerinci mengambarkan bahwa 4\% dari responden menyatakan tidak pernah menggunakan $\mathrm{TI}$ dalam proses belajar mengajar dan 33\% menyatakan kadang-kadang menggunakannya.

Hasil diskusi kelompok terarah juga mengungkapkan hal yang sama mengenai penggunaan $\mathrm{TI}$ dalam proses pembelajaran. Layaknya kondisi yang terjadi pada Kabupaten Tanjung Jabung Barat, guru-guru di Kabupaten Kerinci juga mengalami keterbatasan perangkat teknologi seperti, komputer, laptop dan proyektor/infocus. Sementara untuk akses internet sudah hampir sebagian besar menjangkau SMA di Kabupaten Kerinci.

\section{Kurangnya Pelatihan Dalam Upaya} Peningkatan Kompetensi Guru

Hasil tabulasi angket menunjukkan bahwa pelatihan dianggap paling dibutuhkan untuk meningkatkan kompetensi pedagogik dan profesional guru SMA pada daerah sampel penelitian. Dapat dilihat bahwa pada Kota Jambi, $73 \%$ dari total responden menyatakan membutuhkan pelatihan sedangkan Kabupaten Tanjung Jabung Barat, $60 \%$ dan Kabupaten Kerinci sebanyak 34\%. Permasalahan tentang kebutuhan akan pelatihan guna meningkatkan kompetensi pedagogik dan profesional guru SMA juga muncul dalam hasil diskusi kelompok terbatas. Namun hambatan-hambatan terkait pelatihan untuk guru SMA pada tiap daerah sampel memiliki sedikit perbedaan.

Kepala sekolah SMA Swasta di Kota Jambi menyebutkan bahwa guruguru di sekolah swasta jarang mendapatkan pelatihan jika dibandingkan dengan guru SMA Negeri. Sedangkan pada Kabupaten Tanjung Jabung Barat, para kepala sekolah menyatakan guru mereka membutuhkan jenis pelatihan yang dilaksanakan disekolah (inhouse training) dikarenakan jumlah guru yang tidak memadai dihampir semua sekolah dan jika guru mereka harus mengikuti pelatihan di Kota Jambi, maka akan banyak kelas yang kosong (tidak ada gurunya). Guruguru di Kabupaten Kerinci juga membutuhkan inhouse training, tetapi hampir sebagian besar kepala sekolah menyatakan bahwa sebaiknya Dinas Pendidikan sebagai penyelenggara pelatihan melakukan observasi dan 
bimbingan terhadap guru yang mendapatkan pelatihan. $\mathrm{Hal}$ ini disebabkan bahwa sebagian besar guru yang mengikuti pelatihan tidak menunjukkan perubahan dalam mengajar.

\section{Optimalisasi Musyawarah Guru Mata} Pelajaran (MGMP)

Keterampilan guru dalam mengajar, penguasaan materi pelajaran yang diampu serta variasi serta metode yang digunakan dalam mengajar merupakan keahlian yang dapat diperdalam seiring dengan banyaknya pengalaman dan lamanya guru tersebut mengajar. Selain itu, upaya lain dapat dilakukan guna memperkaya pengalaman dan keahlian guru dalam mengajar adalah melalui suatu forum dimana guru yang memiliki keahlian serumpun berkumpul dan berbagi pengalaman. Forum tersebut dapat berupa Kelompok Kerja Guru (KKG) atau Musyawarah Guru Mata Pelajaran (MGMP).

MGMP sendiri dituntut dapat berperan sebagai : (1) reformator dalam classroom reform, terutama dalam reorientasipembelajaran yang efektif; (2) mediator dalam pengembangan dan peningkatankompetensi guru, terutama pengembangan kurikulum dan sistem pengujian; (3) supporting agency dalam inovasi manajemen kelas; dan (4) manajemen sekolah. (Achmad, 2004).
Hasil diskusi kelompok terbatas dengan kepala sekolah SMA di tiga sampel penelitian juga menyebutkan hal yang sama tentang pentingnya MGMP dalam membantu guru dalam mengatasi permasalahan seperti menyusun Rencana Pembelajaran (RPP), memperdalam materi pelajaran serta memperkaya metode dan variasi pembelajaran. Namun, tidak semua MGMP aktif dalam melaksanakan kegiatan. MGMP yang aktif melakukan pertemuan hanyalah MGMP tertentu yang mendapatkan dana dari program Kementerian Pendidikan.

\section{Kurangnya Apresiasi terhadap guru yang Kreatif dan Berprestasi}

Permasalahan lain yang tidak kalah penting yang muncul dari ketiga diskusi kelompok terbatas adalah terkait dengan fakta bahwa "guru yang kreatif akhirnya capek sendiri". Sebagian besar kepala sekolah pada daerah sampel penelitian mengatakan bahwa cukup banyak guru yang berusaha untuk meningkatkan kompetensi mereka, baik kompetensi pedagogik maupun profesional, dengan menerapkan variasi metode pengajaran, menggunakan media pengajaran dan mengintegrasikan teknologi dan informasi dalam mengajar namun lamakelamaan jumlahnya semakin berkurang. Sebagian kepala sekolah SMA pada sampel penelitian telah 
melakukan usaha memberikan penghargaan sederhana guna memotivasi guru di sekolah mereka agar meningkatkan kompetensi dan kreativitas mereka.

\section{Kesimpulan}

Berdasarkan hasil penelitian tentang peningkatan kompetensi pedagogik dan profesional guru SMA di Provinsi Jambi dapat disimpulkan bahwa :

1. Rata-rata pemahaman kompetensi profesional guru di tiga sampel penelitian dengan skor rata-rata $84,2 \%$ dan kompetensi pedagogik dengan skor rata-rata 81,4\%.

2. Adapun kendala yang dihadapi oleh para guru SMA di Provinsi Jambi dalam rangka peningkatan kompetensi profesional dan pedagogik adalah Minimnya metode dan variasi guru dalam pengajaran, Belum memadainya sarana penunjang pembelajaran, Masih minimnya pemanfaatan $\mathrm{TI}$ dalam Proses Pembelajaran, Kurangnya Pelatihan Dalam upaya peningkatan kompetensi Guru, Optimalisasi Musyawarah Guru Mata Pelajaran (MGMP) dan Kurangnya Apresiasi terhadap guru yang Kreatif dan Berprestasi.

\section{Saran}

1. Kepada Dinas Pendidikan Provinsi dan Kabupaten/Kota serta Pihak
Sekolah untuk mengadakan pendidikan dan pelatihan bagi guru yang langsung menyentuh aspek desain pembelajaran, model penilaian dan evaluasi, mengkaitkan materi dengan pengetahuan lain, keterampilan menggunakan alat pembelajaran strategis teknologi informasi dan melakukan analisis hasil evaluasi dengan model pelatihan yang bisa diadopsi dalam usaha meningkatkan kompetensi pedagogik dan profesional guru, diantaranya adalah Lesson Study, Reflective Teaching, Teacher Professional Development (TPD), Grant Training model In dan On, atau model in-house training lainnya.

2. Penguasaan teknologi informasi dan penggunaan media dalam belajar dapat dilakukan dengan cara pendampingan instruktur secara intensif kepada guru guru yang belum menguasai TIK..

3. Melaksanakan penelitian tindakan kelas (class room action research) dan mempublikasikan hasil penelitiannnya sebagai upaya evaluasi proses pembelajaran dan melihat perkembangan peserta didik selama proses pembelajaran.

4. Terkait dengan sistem penilaian guru, adalah perlu dibuat indeks 
kualifikasi guru berdasarkan kesesuaian ijazah dengan standar persyaratan minimal dan bidang ajar, perlu dibuat indeks kompetensi guru (profesional, pedagogik, kepribadian dan sosial) dimana seluruh aspek penyusunan indeks tersebut diperoleh melalui suatu penilaian yang transparan dan akuntabel, meliputi penilaian diri sendiri, siswa, guru, pengawas sekolah, kepala sekolah, MGMP, Dinas Pendidikan Kabupaten/Kota dan Organisasi Profesi.

5. Optimalisasi peran MGMP melalui kegiatan menyediakan Pembina yang professional (tutor) yang dapat membimbing dan membantu guru dalam meningkatkan kinerja mengajar dan meningkatkan kompetensi professional mereka.

\section{Daftar Pustaka}

Arief Achmad MSP. (2004: 1-2). Memberdayakan mgmp, sebuah keniscayaan. Diambil tangaal 6 Mei 2005 dari http: //artikel.us/artO5-14html

Creswell, J, W. (2011). Education research: planning, conducting, and evaluating quantitative and qualitative research (4th ed). Boston, Pearson Education, Inc.

Darling-Hammond,

(1994).

Performance-based assessment andeducational equity. Harvard Educational Review, 64 (1), 529.

Darling-Hammond, Linda. 2006. Powerful Teacher Education:
Lessons from Exemplary

Programs. San Francisco: Jossey-Bass.

Djamarah, Syaiful Bahri dan Aswan Zain. (2006). Strategi Belajar Mengajar.Jakarta: Rineka Cipta.

Kusnandar. Guru Profesional (Implementasi KTSP dan Sukses Dalam Sertifikasi Guru). Rajawali Pers: Jakarta. 2007.

Lewin, Keith M. and Janet S. Stuart. 2003. "Research Teacher Education: New Perspectives on Practice, Performance and Policy." MUSTER Synthesis Report. Sussex UK:University.

of Sussex and Department for International Development (DFID) Educational Papers.

Mulyasa E. (2007). Standar Kompetensi dan Sertifikasi Guru. Bandung: Remaja Rosdakarya.

Muslich, Masnur. (2007). Kurikulum Tingkat Satuan Pendidikan: Dasar Pemehaman dan Pengembangannya. Jakarta: Bumi Aksara.

Prensky, M. (2004) Digital Game-based Learning (New-York, McGrawHill)

Sanjaya, Wina. 2008. Perencanaan danDesain Sistem Pembelajaran.Jakarta: Kencana Prenada MediaGroup.

Savill-Smith,C. dan Kent, Ph. (2003). The use of palmtop computers for learning: a review of the literature, in: R. Condie \&B.Munro (2007) The Impact of ICT in Schools - A Landscape Review (Coventry, BECTA).

Sunaryo. (2011). Analisis kompetensi guru fisika dalam mengimplemntasikan ktsp di smkn di propinsi lampung. Jakarta: FMIPA UNJ.

Verspoor, Adriaan. 2006. "Schools at the Center of Quality." $A D E A$ Newsletter, Special Issue Biennale 2006: 3-6. 